\title{
Our Newborn Hearing Screening Results of Infants with Congenital Hypothyroidism
}

\section{Konjenital Hipotiroidili Bebeklerde Yenidoğan İşitme Tarama Sonuçlarımız}

\author{
Abitter YUCEL ${ }^{1}$, Cuneyt UGUR²
}

1University of Health Sciences Turkey, Konya Health Application and Research Center, Department of Otorhinolaryngology Head and Neck Surgery, Konya, Turkey

${ }^{2}$ University of Health Sciences Turkey, Konya Health Application and Research Center, Department of Pediatrics, Konya, Turkey

\begin{abstract}
Objective: We aimed to reveal newborn hearing screening test results and risk factors of babies diagnosed with congenital hypothyroidism $(\mathrm{CH})$ in our hospital.

Material and Methods: The files of the newborns who were evaluated within the scope of the national newborn screening program between January and December 2019 were retrospectively reviewed. Risk factors were evaluated by comparing newborn hearing screening test results of babies with $\mathrm{CH}$ and euthyroid control groups.

Results: There was no significant difference between the two groups in terms of demographic and pregnancy datas. There was no significant difference between the $\mathrm{CH}$ and control groups in terms of the rate of failed/passed patients from the hearing screening tests. Patients with thyroid hypoplasia at $\mathrm{CH}$ group failed at a higher rate from the first hearing screening test.
\end{abstract}

Conclusion: In this study, there was no significant difference between $\mathrm{CH}$ and control groups in terms of hearing screening results.

Key Words: Congenital hypothyroidism, Hearing, Newborn screening

öz

Amaç: Bu çalışmada biz, hastanemizde konjenital hipotiroidi (KH) tanısı konan bebeklerde yenidoğan ișitme tarama testi sonuçlarıı ve risk faktörlerini ortaya koymayı amaçladık.

Gereç ve Yöntemler: Ocak-Arallk 2019 tarihleri arasında hastanemizde ulusal yenidoğan tarama programı kapsamında değerlendirilen yenidoğanların dosyaları retrospektif olarak incelendi. KH ve ötiroid kontrol gruplarının yenidoğan işitme tarama testi sonuçları karşılaştıılarak risk faktörleri değerlendirildi.

Bulgular: Iki grup arasında demografik ve gebeliğe ait veriler açısından anlamlı bir fark yoktu. KH ve kontrol grupları arasında işitme tarama testlerinden kaldı/geçti hasta oranı açısından anlamlı fark yoktu. KH grubunda tiroid hipoplazisi olan hastalar ilk işitme tarama testinden daha yüksek oranda başarısız oldular.

Sonuç: Bu çalışmada, KH ile kontrol grupları arasında işitme tarama sonuçları açısından anlamlı bir fark yoktu.

Anahtar Sözcükler: Konjenital hipotiroidi, İșitme, Yenidoğan tarama

(1)

YUCELA UGUR C

Conflict of Interest / Çıkar Çatışması: On behalf of all authors, the corresponding author states that there is no conflict of interest.

: 0000000264330362 Ethics Committee Approval / Etik Kurul Onayı: The study was approved by KTO Karatay University, Drug and Non-Medical Device Research Ethics Committee : 0000000262607719 (with number: 41901325-050.99).

Contribution of the Authors / Yazarların katkıs: YUCEL A: Constructing the hypothesis or idea of research and/or article, Planning methodology to reach the Conclusions, Organizing, supervising the course of progress and taking the responsibility of the research/study, Taking responsibility in patient follow-up, collection of relevant biological materials, data management and reporting, execution of the experiments, Taking responsibility in logical interpretation and conclusion of the results, Taking responsibility in necessary literature review for the study, Taking responsibility in the writing of the whole or important parts of the study, Reviewing the article before submission scientifically besides spelling and grammar. UGUR C: Constructing the hypothesis or idea of research and/or article, Planning methodology to reach the Conclusions, Organizing, supervising the course of progress and taking the responsibility of the research/study, Taking responsibility in patient follow-up, collection of relevant biological materials, data management and reporting, execution of the experiments, Taking responsibility in logical interpretation and conclusion of the results, Taking responsibility in necessary literature review for the study, Taking responsibility in the writing of the whole or important parts of the study, Reviewing the article before submission scientifically besides spelling and grammar.

How to cite / Atıf yazım şekli : Yucel A, Ugur C. Our Newborn Hearing Screening Results of Infants with Congenital Hypothyroidism. Turkish J Pediatr Dis 2021;15:203207. 


\section{INTRODUCTION}

Congenital hypothyroidism $(\mathrm{CH})$ is one of the most common endocrine pathologies in childhood, and its frequency is 1 : 3000/4000 live births (1). Normal levels of free thyroxine (fT4) and thyroid stimulating hormone (TSH) levels can vary according to age in children. According to normal values at the age of the child, if fT4 is below the lower limit and TSH is above the upper limit, then the diagnosis of $\mathrm{CH}$ is made. TSH levels above 10 $\mathrm{mUI} / \mathrm{L}$ and low FT4 values confirm the diagnosis of primary hypothyroidism (2). $\mathrm{CH}$ can be permanent or temporary. The most common cause of permanent primary $\mathrm{CH}$ is dysgenesis $(80-85 \%)(3,4)$.

Thyroid hormones play an important role in the development of the nervous system in the first years of life. Therefore, delay of diagnosis in severe hypothyroidism leads to significant and permanent mental and motor developmental deficiency (3). The formation of the inner ear structures and the development of auditory function depends on adequate thyroid hormone levels. Lack or insufficiency of thyroid hormone in the early developmental ages can damage the sensory structures of the inner ear (5).

Congenital hypothyroidism screening has been carried out since 2006, and neonatal hearing screening has been carried out since 2004 in our country $(6,7)$. With this study, we aimed to reveal newborn hearing screening test results and risk factors of babies diagnosed with $\mathrm{CH}$ in our hospital.

\section{MATERIALS and METHODS}

The files of the newborns who were evaluated within the scope of the national newborn screening program in our hospital between January and December 2019 were analyzed retrospectively. $\mathrm{CH}$ was defined as concentration of $\mathrm{fT} 4<0.7$ $\mathrm{ng} / \mathrm{dl}$ with $\mathrm{TSH}>10 \mathrm{mlU} / \mathrm{L}$. Babies were divided into two groups according to their blood thyroid hormone levels; $\mathrm{CH}$ group $(\mathrm{n}=$ 61) and control group ( $n=50$, fT 4: 0.70-1.74 ng/dl and TSH 0.57- $5.6 \mathrm{mlU} / \mathrm{L})$. Age, gender, birth weight, gestational age, type of birth, multiple birth status, maternal age, TSH and fT4 levels and newborn hearing screening test results of both groups were recorded. Newborn hearing screening test was performed with screening auditory brainstem responses (ABR)device (MADSEN AccuScreen ABR). Each patient underwent routine otoscopic examination before testing. Screening ABR result was automatically reported as "passed" or "failed". If a baby passed the screening test in one ear and failed from the other ear, that baby was included in the failed group. Babies who failed from the first screening test were called for a repeat test two weeks later. While the patients who passed the second screening ABR test were considered as "passed", the remainder of the test were defined as "referred" and redirected to secondary center for a definitive diagnosis in terms of hearing. Those with temporary CH, Toxoplasma, Rubella, Cytomegalovirus, Herpes (TORCH) group infection during pregnancy, consanguineous marriage, familial hearing loss, premature and low birth weight, neonatal hyperbilirubinemia, craniofacial anomaly, intensive care and ototoxic drug use history were excluded from the study. The study was approved by KTO Karatay University, Drug and Non-Medical Device Research Ethics Committee (with number: 41901325-050.99).

\section{Statistical Analysis:}

Descriptive statistics were used to compare the general characteristics of all participants. Test of Normality, including Kolmogorov-Smirnov and Shapiro-Wilk tests, was used to determine the distribution of data. The data with normal distribution were given as mean \pm standard deviation and the data with no normal distribution were given as median (interquartile range) and median (interquartile range) (minimummaximum). Categorical variables were shown as number ( $n$ ) and percentage (\%). The comparison of the numerical data between groups was performed with the appropriate test from Independent Samples $T$ and Mann-Whitney $U$ tests. Chi-square and Fisher's exact tests were used to compare categorical variables. Statistical Package for Social Sciences (SPSS) Windows software (ver. 22; IBM SPSS, Chicago, USA) was used for all statistical analyses. $P$ value less than 0.05 was considered as statistically significant.

\section{RESULTS}

A total of 111 patients were included in this study. While 61 of these patients belonged to the $\mathrm{CH}$ group, 50 belonged to the control group.The median age of both groups was 30 days. While there were 31 (50.8\%) female and 30 (49.2\%) male in the $\mathrm{CH}$ group, there were 21 (42\%) female and 29 (58\%) male in the control group. There was no significant difference between the two groups in terms of age and gender ( $p>0.05$ ).

The median gestational age of the $\mathrm{CH}$ group was 39 weeks, while the control group was 40 weeks. There was no significant difference between the two groups in terms of birth weight and gestational age $(p>0.05)$. In the $\mathrm{CH}$ group, $34(55.7 \%)$ babies were born by vaginally, 27 (44.3\%) babies were delivered by cesarean section, while in the control group $30(60 \%)$ babies were born by vaginally, and 20 (40\%) babies were born cesareanly. The median mother age of both groups was 28 years. There was no significant difference between the two groups in terms of delivery method and median mother age ( $p>0.05$ ). While the median TSH level of the $\mathrm{CH}$ group was 19.4 $\mathrm{mUI} / \mathrm{L}$ the control group was $2.8 \mathrm{mUI} / \mathrm{L}$. The median fT 4 level of the $\mathrm{CH}$ group was $1.16 \mathrm{ng} / \mathrm{dl}$ and the control group was 1.25 $\mathrm{ng} / \mathrm{dl}$. The differences in TSH and fT4 levels between the two groups were statistically significant ( $p<0.01$ for both) (Table I). 
Table I: Distribution of demographic, laboratory and pregnancy data of both groups.

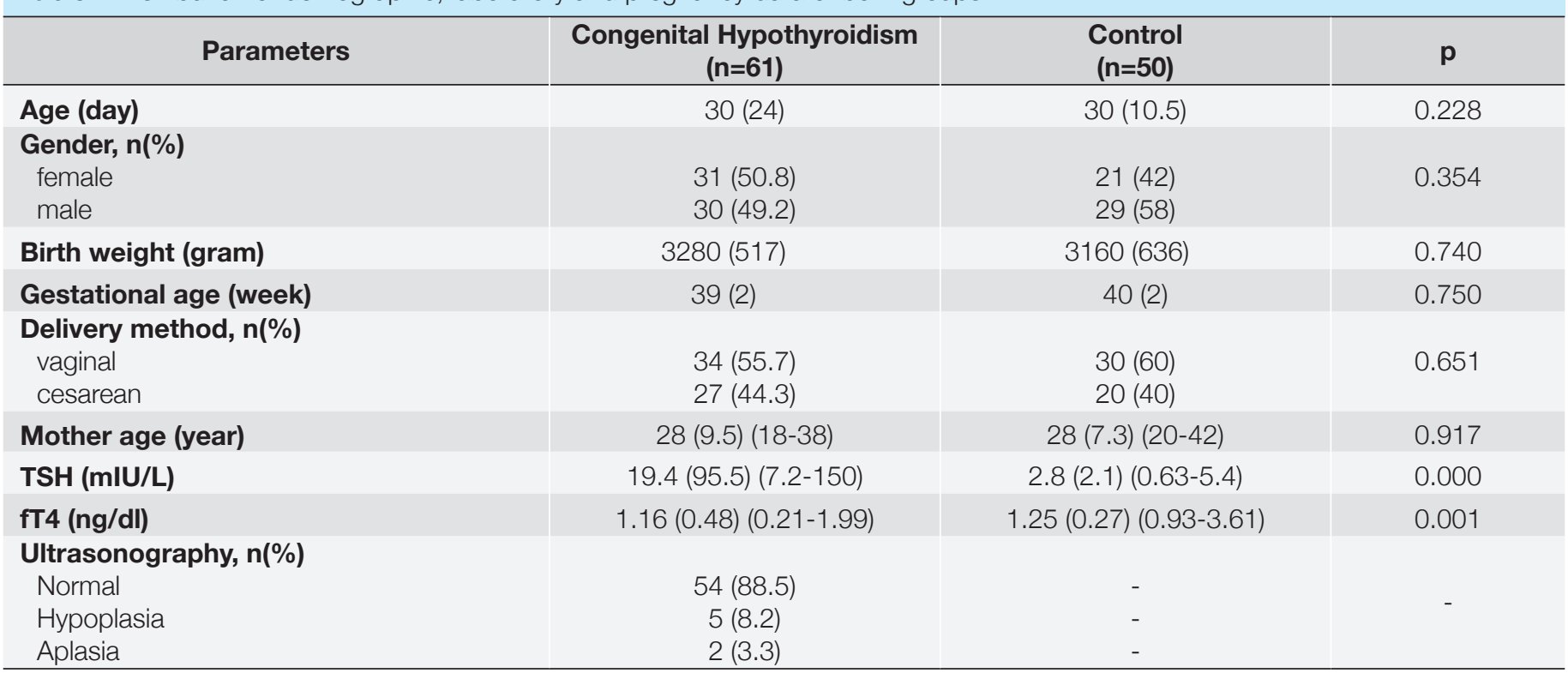

IR: Interquartile Range, Note: Parameters expressed as n (\%), median (IR) and median (IR) (minimum-maximum).

Table II: Distributions of "passed" and "failed" numbers of both groups from hearing screening tests.

\begin{tabular}{l|c|c|c}
\hline \multicolumn{1}{c|}{ Groups } & $\begin{array}{c}\text { First screening test } \\
\text { passed / failed } \\
\mathbf{n} / \mathbf{n}\end{array}$ & $\begin{array}{c}\text { Second screening test } \\
\text { passed / failed } \\
\mathbf{n} / \mathbf{n}\end{array}$ & $\begin{array}{c}\text { Referred } \\
\mathbf{n}\end{array}$ \\
\hline Congenital Hypothyroidism (n=61) & $52 / 9$ & $7 / 2$ & 2 \\
Control $(\mathbf{n}=\mathbf{5 0})$ & $43 / 7$ & $7 / 0$ & 0 \\
\hline
\end{tabular}

Table III: Distributions of thyroid parameters of $\mathrm{CH}$ group who passed and failed from the first screening test.

\begin{tabular}{|c|c|c|c|}
\hline Parameters & $\begin{array}{c}\text { CH Group } \\
\text { passed first screening test } \\
n=52\end{array}$ & $\begin{array}{c}\text { CH Group } \\
\text { failed first screening test } \\
n=9\end{array}$ & p \\
\hline $\begin{array}{l}\text { Ultrasonography, n (\%) } \\
\text { Normal } \\
\text { Hypoplasia } \\
\text { Aplasia }\end{array}$ & $\begin{array}{l}48(89.9) \\
2(40) \\
2(100)\end{array}$ & $\begin{array}{l}6(11.1) \\
3(60) \\
0(0)\end{array}$ & 0.039 \\
\hline TSH (mIU/L) & $16.9(92.81)$ & 41.12 (139.27) & 0.312 \\
\hline
\end{tabular}

CH: Congenital Hypothyroidism, Note: Parameters expressed as $n$ (\%) and median (Interquartile Range)

While 52 patients in the $\mathrm{CH}$ group passed the first hearing screening test, 9 patients failed from this test. In the control group, 43 patients passed the first hearing screening test, while 7 patients failed from the test. In the second hearing screening test, 7 out of 9 patients in the $\mathrm{CH}$ group passed the test and the remaining 2 patients were referred to the experienced hearing center with the diagnosis of hearing loss. In the control group, all patients who failed from the first test passed from the second hearing test.There was no significant difference between the two groups in terms of the rate of failed/passed from hearing screening tests $(p>0.05)$ (Table II).

When the $\mathrm{CH}$ group was divided into two group according to the first hearing test result (passed and failed); Of those who passed the first test, 48 patients had normal thyroid ultrasonography, 2 patients had thyroid hypoplasia and 2 patients had thyroid aplasia.In the failed group of the first screening test, 6 patients had normal thyroid ultrasonography, 3 patients had thyroid hypoplasia, there were no patients with thyroid aplasia in this group. There was a significant difference between the two groups in terms of thyroid hypoplasia and it was found that patients with thyroid hypoplasia failed at a higher rate from the first hearing screening test. However, there was no significant difference between these two groups in terms of TSH and fT4 levels (Table III). 


\section{DISCUSSION}

It has long been known that thyroid hormone is required for the normal and complete development of the hearing system and hearing loss may be associated with thyroid dysfunction. Although many structures of the hearing system depend on thyroid hormone, it has been reported that the most sensitive area is outer hair cells in a experimental $\mathrm{CH}$ animal model (8). The absence or decrease of thyroid hormone can cause changes in cochlear function and structure. In an animal model, the presence of scars in the cochlea of $\mathrm{CH}$ rats has been demonstrated, and it has been claimed that the largest lesions are concentrated in the apical region of the cochlea (9).

The prognosis of patients with $\mathrm{CH}$ significantly improved after the start of screening programs. It has been reported that $20-36 \%$ of cases had severe bilateral hearing impairment in studies conducted on children with sporadic $\mathrm{CH}$ prior to the widespread use of newborn screening programs (10). However, despite significant improvements in recent years, hearing loss still remains an important problem, especially in patients with severe $\mathrm{CH}$. In the audiological examination of 32 patients who were followed up with a diagnosis of $\mathrm{CH}$, the risk of hearing loss was higher in $\mathrm{CH}$ young patients than age-matched controls without $\mathrm{CH}$, and $25 \%$ of patients showed mild and subclinical hearing impairment despite early and adequate replacement therapy, and the risk of hearing loss was closely related to the severity of $\mathrm{CH}$. The authors also stated that all $\mathrm{CH}$ children with athyreosis and delayed bone maturation should be carefully evaluated and included in a close monitoring program (11). Also, Belmann et al. (10) stated that despite early treatment, children with $\mathrm{CH}$ had mild hearing impairment, but the severity of hearing loss was less than the period before screening programs started. Lictenberger et al. (12) reported that hearing loss was associated with the type of $\mathrm{CH}$, severity of the disease, and delayed bone maturation at the time of diagnosis. In addition, they reported that patients with athyreosis and with normal gland at anatomical location were affected more frequently than those with ectopic thyroid glands.In this study, although there was no significant difference between the $\mathrm{CH}$ and control groups in terms of hearing screening test results, in the $\mathrm{CH}$ group it was found that babies with thyroid hypoplasia failed at a higher rate from the first hearing screening test than babies without. Therefore, we think that patients with thyroid hypoplasia should be followed carefully for hearing screening tests. However, we should also note that the number of patients with thyroid aplasia was low due to the limited number of patients in our study. It should also be kept in mind that this situation may have caused the results of patients with aplasia to be non-significant. Also, when the second screening test results were evaluated, the same situation was not observed.

In a study, no correlation was found between outer hair cell dysfunction and hypothyroidism. The authors claimed that T4 deficiency in the cochlea's maturation stage did not affect the outer hair cell biological activity in the first month after birth (13). In a study that was found to have a high incidence of 'refer' in the screening of patients with $\mathrm{CH}$, it was stated that this increased referral number may indicate preclinical cochlear sensitivity associated with hypothyroidism (13). In another study, it was found that there was no significant difference between the groups with and without $\mathrm{CH}$ in terms of transient evoked otoacoustic emissions (TEOAE) amplitudes. However, it was determined that there was a moderate correlation between TEOAE amplitudes and TSH and fT4 levels, and thyroid hormone levels had an effect on auditory responses (14). Although there are publications reporting that there is no difference in terms of OAE responses between those with and without $\mathrm{CH}$, we think that it should be kept in mind that maternal support extends until delivery in the presence of dyshormonogenesis or agenesis at fetus. In our study, we found that there was no significant difference between the $\mathrm{CH}$ group and the control group in terms of newborn hearing screening test results. As we just mentioned, we thought that this result may contribute to the development of inner ear structures with the support of thyroid hormones caused from maternal system. Therefore, although there was no significant difference the groups in terms of hearing screening test results in our study, we recommend to follow these babies closely in terms of hearing levels. Andrade et al. (5) stated that although there were OAE responses in individuals with $\mathrm{CH}$, the OAE response signal was decreased especially in the middle frequencies compared to normal individuals, therefore the bioelectromechanical mechanisms of the cochlea can be in danger in this population. The authors stated that these findings may indicate subclinical impairments.

The main limitation of this study is the low number of patients. Also, the exact diagnosis of the patient referred with the diagnosis of hearing loss were not known.

In this study, hearing screening test results of healthy newborns and $\mathrm{CH}$ patients with similar demographic and maternal features were compared. There was no significant difference between the two groups in terms of hearing screening test results. It was observed that $\mathrm{CH}$ patients with thyroid hypoplasia failed at a higher rate from the first screening test. Similarly, among $\mathrm{CH}$ patients who passed and failed from the first screening test, the TSH levels of those who failed from the first test were higher, although there was no significant difference in terms of TSH levels. Therefore, patients with high TSH levels or thyroid hypoplasia should be followed carefully in terms of hearing. Although there was no significant difference between the babies with $\mathrm{CH}$ and the control groups in terms of hearing screening results, we recommend that these patients should be followed closely in terms of hearing in their later life.

\section{REFERENCES}

1. American Academy of Pediatrics (AAP); American Thyroid Association (ATA); Lawson Wilkins Pediatric Endocrine Society 
(LWPES). Update of newborn screening and therapy for congenital hypothyroidism. Pediatrics 2006;117:2290-303.

2. Maciel LM, Kimura ET, Nogueira CR, Mazeto GM, Magalhães PK, Nascimento PL, et al. Congenital hypothyroidism: recommendations of the thyroid department of the Brazilian society of endocrinology and metabolism. Arq Bras Endocrinol Metabol 2013; 57: 184-92.

3. Özon A, Tekin N, Şıklar Z, Gülcan H, Kara C, Taștekin A, et al. Gebelikte tiroid hastalıklarının neonatal etkileri ve TSH yüksekliği olan bebeğe yaklaşım: Türk Neonatoloji ve Çocuk Endokrinoloji ve Diyabet Dernekleri uzlaşı raporu. Turk Pediatri Ars 2018; 53: 20923.

4. Jain V, Argawal R, Deorari AK, Paul VK. Congenital hypothyroidism. Indian J Pediatr 2008;75:363-7.

5. De Andrade CLO, Machado GC, Magalhães LPF, Cerqueira TLO, Fernandes LC, Ramos HE et al. Cochlear dysfunction evidenced by reduction of amplitude of otoacustic responses in patients with congenital hypothyroidism. Int J Pediatr Otorhinolaryngol 2019; 122: 12-7.

6. Ovalı P. Yenidoğan Taramaları. Klinik Tıp Pediatri Dergisi 2019; 11: 193-9.

7. Arıcıgil M, Ulutaş RA, Yücel A, Arbağ H. Yenidoğan İşitme Tarama Sonuçlarımız. Selçuk Med J 2015;31: 121-3.

8. Li D, Henley CM, O'Malley Junior BW. Distortion product otoacoustic emissionsand outer hair cell defects in the hyt/hyt mutant Mouse. Hear Res 1999; 138: 65-72.
9. Mustapha M, Frang Q, Gong TW, Dolan DF, Raphael Y, Camper $\mathrm{SA}$, et al. Deafness and permanently reduced potassium channel gene expression and function in hypothyroid Pit $1^{\text {dw }}$ mutants. J Neurosci 2009; 29: 1212-23.

10. Bellman SC, Davies A, Fuggle PW, Grant DB, Smith I. Mild impairment of neuro-otological function in early treated congenital hypothroidism. Arch Dis Child 1996; 74: 215-8.

11. Bruno R, Aversa T, Catena M, Valenzise M, Lombardo F, De Luca $\mathrm{F}$, et al. Even in the era of congenital hypothyroidism screening mild and subclinical sensorineural hearing loss remains a relatively common complication of severe congenital hypothyroidism. Hear Res 2015; 327: 43-7.

12. Lichtenberger-Geslin L, Dos Santos S, Hassani Y, Ecosse E, Van Den Abbeele T, Léger J. Factors associated with hearing impairment in patients with congenital hypothyroidism treated since the neonatal period: a national population-based study. J Clin Endocrinol Metab 2013; 98: 3644-52.

13. Parazzini M, Ravazzani P, Medaglini S, Weber G, Fornara C, Tognola G, et al. Click-evoked otoacustic emissions recorded from untreated congenital hypothyroid newborns. Hear Res. 2002; 166: 136-42.

14. Machado GC, Oliveira de Andrade CL, da Cruz Fernandes L, Morais de Albuquerque J, Franco Magalhães LP, et al. Study of cochlear function in neonates and infants with congenital hypothyroidism. Int J Pediatr Otorhinolaryngol 2019; 124: 203-7. 